\title{
Aquatic system response to climatic and human changes: productivity, bottom water oxygen status, and sapropel formation in Lake Lugano over the last 10000 years
}

\author{
F. Niessen ${ }^{1}$, L. Wick ${ }^{2}$, G. Bonani ${ }^{3}$, C. Chondrogianni ${ }^{4}$ and C. Siegenthaler ${ }^{5}$ \\ 1 Geologisches Institut, ETH-Zentrum, CH-8092 Zürich, Switzerland \\ 2 Systematisch-Geobotanisches Institut der Universität Bern, Altenbergrain 21, CH-3013 Bern, \\ Switzerland \\ ${ }^{3}$ Institut für Mittelenergiephysik, ETH-Hönggerberg, CH-8093 Zürich, Switzerland \\ ${ }^{4}$ Limnologisches Institut, Universität Konstanz, Mainaustr. 212, DW-7750 Konstanz, Germany \\ 5 EAWAG, CH-8600 Dübendorf, Switzerland
}

Key words: Lake Lugano (Lago di Lugano), palaeolimnology, Holocene, organic and inorganic carbon, biogenic silica, ostracoda, oligochaeta cocoons, laminated sediments, pollen, soil erosion, eutrophication.

\begin{abstract}
The Holocene record of Lake Lugano (southern basin: surface area $20.3 \mathrm{~km}^{2}$, maximum depth $87 \mathrm{~m}$ ) comprising organic carbon-rich sediments (sapropels), is divided into eight intervals based on radiocarbon- and varve-dating. The content of organic carbon, inorganic carbon, and biogenic silica, as well as the benthic remains of ostracods and oligochaetes, are converted into accumulation rates and benthic abundances in order to assess past production rates and bottom water oxygen status, respectively. The results suggest three periods of distinct palaeolimnological character: (i) low primary production combined with shifts between aerobic and anaerobic profundal conditions (prior to ca. $3000 \mathrm{BC}$ ), (ii) moderate rates of production combined with a relatively high profundal oxygen content (after ca. $1500 \mathrm{BC}$ ), and (iii), high production rates $\left(460 \mathrm{~g} \mathrm{C} \mathrm{m}^{-2} \mathrm{a}^{-1}\right)$ combined with anaerobic profundal conditions (present eutrophic state). Corresponding organic carbon contents in the sediments are: up to $5 \%$ (i), $4 \%$ (ii), and $8 \%$ (iii). Until the beginning of this century, the flux of autochthonous sediments to the lake floor correlated with the fluctuations in the allochthonous sediment accumulation rate, indicating that catchment erosion largely controlled lacustrine production during the Holocene history of Lake Lugano. Pollen data show catchment-vegetational transformations at ca. $3500 \mathrm{BC}$ (change from fir to beech forests), at $1400 \mathrm{BC}$ (onset of cereal vegetation) and at ca. A.D. 450 (strong increase in various cultural plants). The first two changes had a relatively large imprint on lacustrine sedimentation. At ca, $3500 \mathrm{BP}$, erosion increase in the catchment was triggered by vegetation changes in the mountain zone above ca. $1000 \mathrm{~m}$ a.s.l., which may have been induced by climatic and human alteration (drop in the treeline altitude). Maximum catchment erosion occurred at ca. $1400 \mathrm{BC}$ which was clearly dominated by human cultivation during the Bronze Age. More oxygenated profundal conditions in the lake after ca. $3000 \mathrm{BC}$ are possibly related to a better mixing of the lake waters during the winter season by increased wind activity.
\end{abstract}




\section{Introduction}

The reconstructions of primary production and bottom-water oxygen conditions from organic carbon-rich lake sediments provide information about the effects of anthropogenic and climatic impacts on lacustrine ecosystems, which can then be used to model the formation of organic rich sediments widely found in the geologic record. Black laminated sapropels are commonly associated with anaerobic or dysaerobic $\left(0.1\right.$ to $\left.1.0 \mathrm{mlO}_{2} / 1\right)$ bottom water conditions, which can in turn be related to high primary production rates and/or sluggish deep water mixing rates (Demaisson \& Moore, 1980). However, Pedersen \& Calvert (1990) argue that the formation of organic carbon-rich marine sediments is not restricted to anoxic deep water because decomposition of organic matter under anaerobic conditions may be as efficient as under aerobic conditions. They suggest that burial rates of organic carbon is largely a function of productivity. Thus the understanding of palaeoenvironments for basins accumulating organic matter requires an assessment of both past production rates and bottom water oxygen contents. Here we present such a case study for the Holocene history of the southern basin of Lake Lugano, a deep, fjord-like lake located at the Swiss-Italian border (Fig. 1).

During the last few decades Lake Lugano has been significantly affected by eutrophication (Barbieri \& Mosello, Polli \& Simona, this issue). Today the deep water environment in the southern basin is seasonally anoxic (Lazaretti et al., this issue). As a result, laminated organic rich sediments (varves) were deposited during the last few decades (Niessen, 1987). In addition, the entire Holocene record of the basin is characterized by black, in parts distinctly laminated muds with organic carbon contents ranging between 2 and $12 \%$ (Niessen, 1987; Niessen \& Kelts, 1989). Based on qualitative evidence such as content of organic carbon and calcite/dolomite ratios, the authors conclude that Lake Lugano had variable production rates during the Holocene. Production was particularly low during the early Holocene " climatic optimum" then increased around 4000 years BP. This paper provides a more quantitative assessment by using accumulation rates of organic carbon, autochthonous calcite and biogenic silica as measures of past production rates.

Our working hypothesis is that high lacustrine production rates should be accompanied by increased accumulation rates of autochthonous sediments, as is the case today for eutrophic lake conditions. In addition, if decreased bottom water oxygen contents for the past are indicated by lack of benthic fossils and/or preservation of laminae, the associated accumulation rates may indicate whether the oxygen deficiency is due to high production or sluggish deep water circulation. The aim of this study is: (i) to understand the formation of organic rich sediments in the southern basin of Lake Lugano for the last 10000 years and, (ii), to analyze how palaeolimnological shifts may be related to climatic or human induced changes in catchment vegetation and erosion. The latter should be indicated by pollen evidence and accumulation of detrital sediments. 


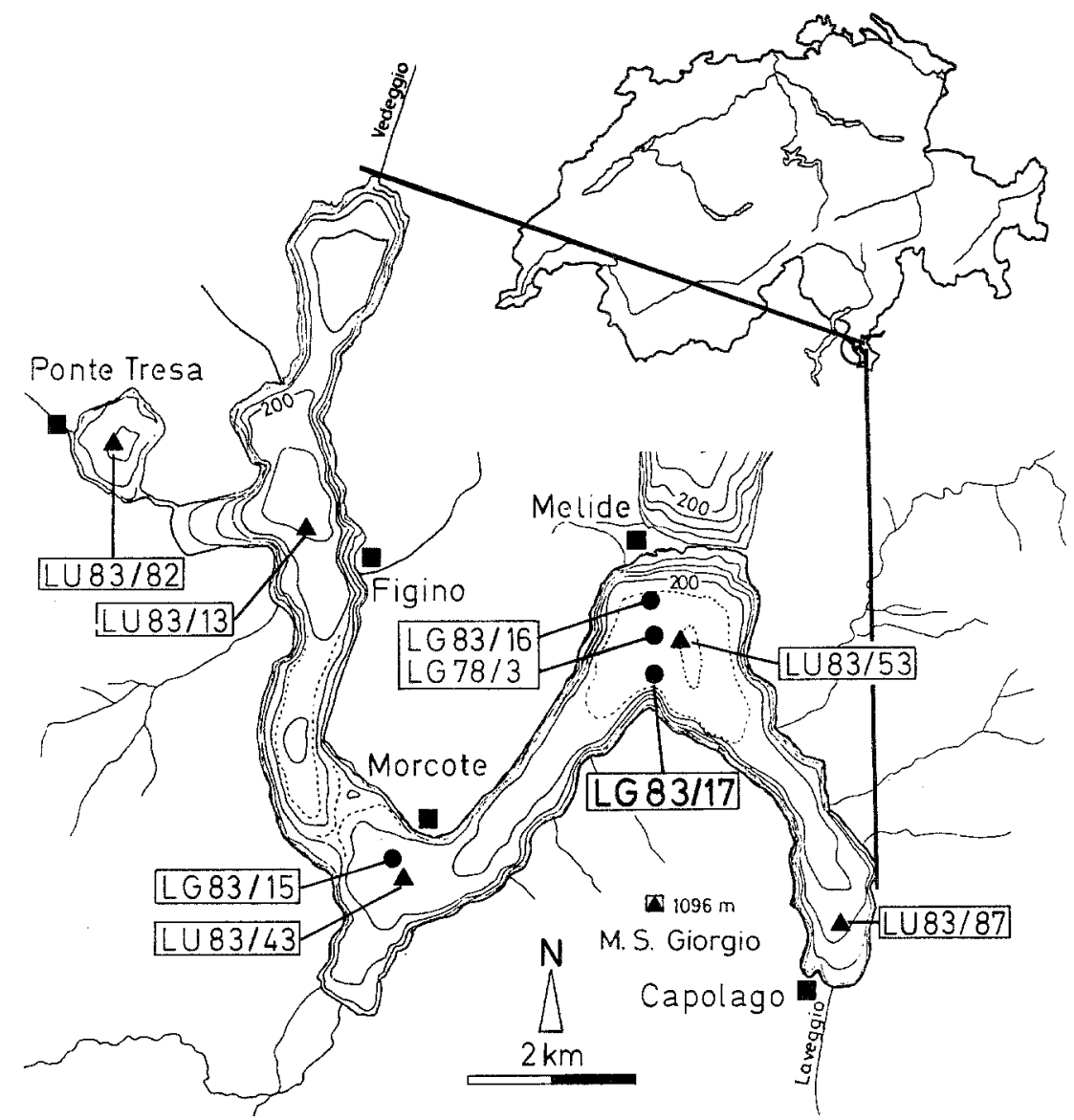

Figure 1. Geographic situation and sampling sites (southern basin, Lake Lugano; isobaths $20 \mathrm{~m}$ intervals, maximum water depth $87 \mathrm{~m}$ ). $\mathrm{LU}=$ short cores up to $1 \mathrm{~m}$ length (after Geologisches Institut, ETHZ, 1984). $\mathrm{LG}=$ piston cores up to $13 \mathrm{~m}$ length (after Niessen, 1987).

\section{Stratigraphic setting and data-base}

The sedimentary record of the eutrophication of Lake Lugano during this century is known from several short-core studies (Züllig, 1982; Geologisches Institut ETHZ, 1984; Niessen 1987; Fig. 1). The latest Glacial and Holocene sedimentary record from the southern basin was studied using several long cores (78/3, LG 83/15, /16, /17; Fig. 1 and 2) as part of the first author's PhD-thesis (Niessen, 1987).

The thickness of the Holocene fill is relatively uniform over large areas in the lake's southern basin (Fig. 2). The record, except for the deposits of this century, is generally dominated by allochthonous sediments, mostly silicates such as quartz, feldspars and layer silicates (Niessen, 1987). The core LG 83/17, also used for this study (Fig. 3), is one of the best dated sections for large lakes in the peri-Alpine area and includes a radiocarbon/geomagnetic chronology (Niessen \& Kelts, 1989) and a 


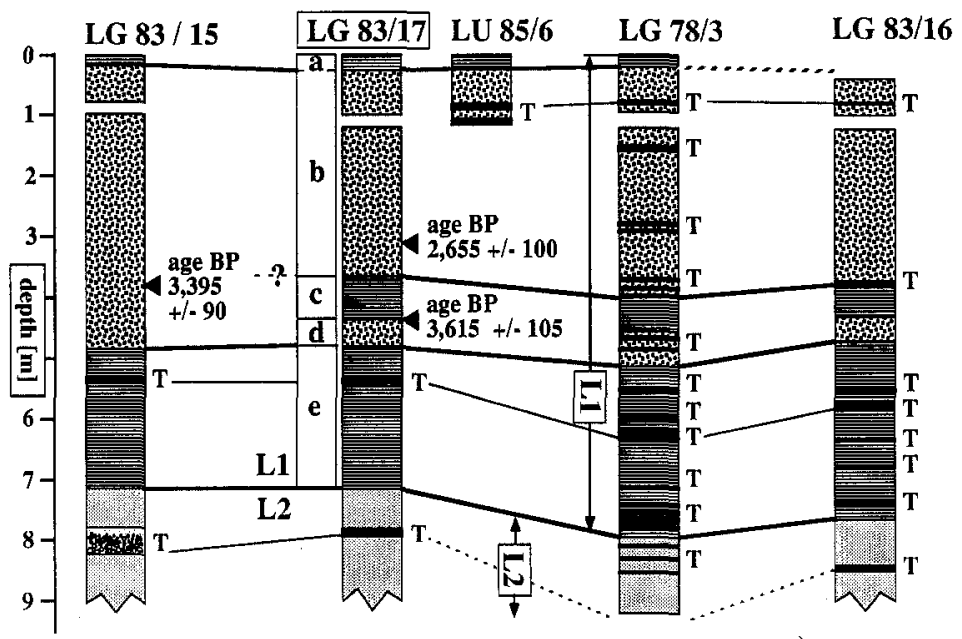

Figure 2. Correlation of unit 1 sediments in the southern basin of Lake Lugano. The larger thickness in core LG 78/3 relative to other Holocene sections is related to a higher proportion of turbidite beds (T) in the deepest part of the basin. Core locations are given in Fig. 1 (redrawn after Niessen, 1987; ${ }^{14} \mathrm{C}$ ages from Niessen, 1987, and Niessen \& Kelts, 1989).

pollen stratigraphy from 14600 to 2500 BP (Wick, 1989; Fig. 4). Niessen \& Kelts (1989) describe 4 lithological units (L 1 to L 4) for the last 15000 years. The differences between the Holocene (unit L1, which is used in this study) and the latest Pleistocene (unit L 2) are distinct: L 2 is light in colour and low in organic carbon $(0-1 \%)$ whereas L1 is dark-gray to black in colour and high in organic carbon (up to $8 \%$, Fig. 3). The definition of 5 Holocene lithological sub-units (L1 a to L 1e) is based on sedimentary fabric: Generally, L1 a, c, and e are well laminated, whereas b and d show indistinct or, in places, no laminations (Fig. 3 and 6). The top of the section (L1a) is varved and comprises 60 calcite/diatom laminae couplets (Tab. 1).

Several sedimentary parameters, originally determined and discussed by Niessen (1987), form the data-base for this study (Fig. 5, 6, 7, Tab. 1). These include organic and inorganic carbon, biogenic silica (opal); calcite/dolomite ratios; counts of macrobenthic fossils, and the stable carbon isotope signatures $\left(\delta^{13} \mathrm{C}\right)$ in benthic ostracod valves. Inorganic carbon is related to calcite $\left(\mathrm{CaCO}_{3}\right)$, mostly autochthonous, and dolomite $\left(\mathrm{Ca}, \mathrm{Mg}\left(\mathrm{CO}_{3}\right)\right)$, which is entirely allochthonous. The trends for organic and inorganic carbon, biogenic silica, calcite/dolomite ratios, and benthic fossils in core LG 83/17 are also present in core LG 83/15. Thus the trends in core LG 83/17 used for this study can be expected to have had a basin-wide presence (see Fig. 1 and 2 for core location and stratigraphic correlation).

\section{Materials and methods}

The data presented here were obtained from core LG 83/17 and from several short cores (Fig. 1). Calender-year calibration was done according to Linik et al. (1986) for 
Table 1. Summary of cited data, calculations and results. $\left({ }^{14} \mathrm{C}\right.$-results are from Niessen $\&$ Kelts, 1989; sediment components are expressed as mean values in time intervals after Niessen, 1987, and Niessen, 1990). For methodological details with respect to the original data the readers are referred to the mentioned publications. Core LG $85 / 6$ is a short core taken at the same site as LG 83/17 in 1985 (Fig. 1).

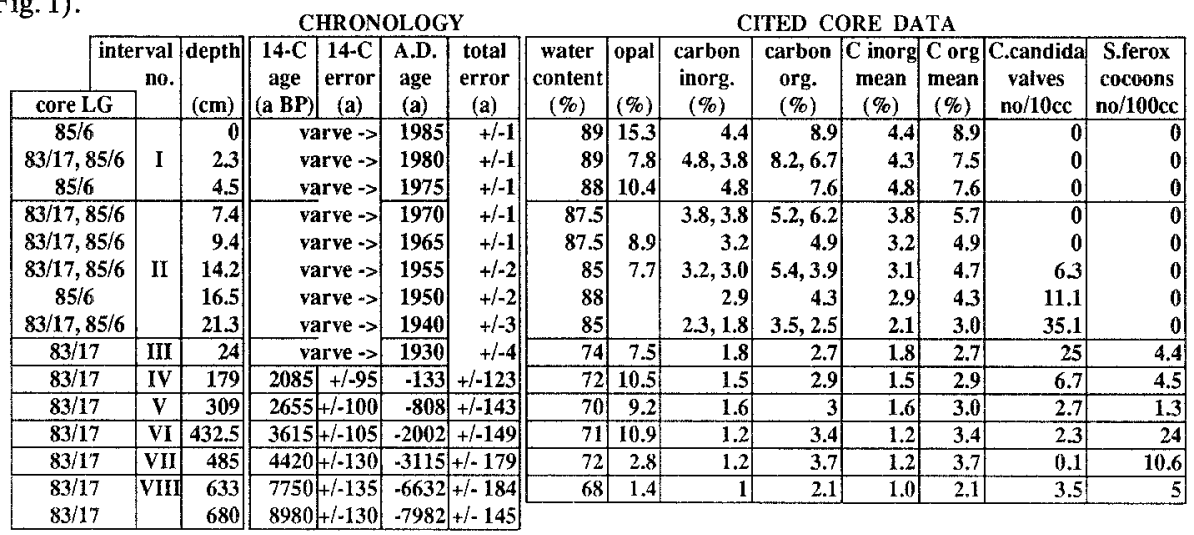

${ }^{14} \mathrm{C}$ ages younger than 8000 years BP and according to Stuiver et al. (1991) for ages older than 8000 years BP. The ${ }^{14} \mathrm{C}$ data (Accelerator Mass Spectrometry) published by Niessen \& Kelts (1989) are used for this purpose. Dating of the topmost laminated section (unit L 1 a) is derived from varve counting as described by Züllig (1982) and Niessen (1987). Average values of sediment components (carbon, opal) are calculated from the original data (Niessen, 1987) using the component mean between two ${ }^{14} \mathrm{C}$ dated points as summarized in Tab.1. The pollen analysis is described in detail by Wick (1989). Results from PAZ 14 and 15 confirm that the sediment gap in core LG 83/17, due to the coring operation (Fig. 3), is of the order of $20 \mathrm{~cm}$.

Bulk Sediment Accumulation ( $B S A)$ is obtained from equations (1) to (3):

$$
\begin{aligned}
& B S A=s \cdot \varrho_{s} \cdot(1-\Phi) \\
& \Phi=\frac{w \cdot \varrho_{s}}{w \cdot \varrho_{s}+(1-w) \cdot \varrho_{w}}=\text { porosity (Berner, 1971) } \\
& \varrho_{s} \approx-0.047 \cdot c o+2.6=\text { dry density of sediments }
\end{aligned}
$$

with:

$s=$ average sedimentation rates between two dated points in cored sediments, $\varrho_{w}=$ pore-water density $\left(1.0 \mathrm{~kg} \mathrm{~m}^{-3}\right)$,

$w=$ water content (weight $\%$ of water relative to the total wet sediment weight), $c o=$ content of organic carbon (weight \%)

The Component Sediment Accumulation (CSA) is defined by:

$$
C S A=B S A \cdot C / 100
$$

with: $\mathrm{C}=$ component in weight percent relative to the total dry weight. 
The sum of Autochthonous Sediments Compounds $(\Sigma A S C)$ is defined as:

$$
\Sigma A S C=\mathrm{CaCO}_{3 \text { autochthonous }}+\mathrm{SiO}_{2 \text { diatom }}+\mathrm{CH}_{2} \mathrm{O}_{\text {organic matter }}
$$

Late Glacial sediments from core LG 83/17 (ca. $13 \mathrm{ka} \mathrm{BP}$ ), consisting of detrital muds derived from local catchment runoff, offer the opportunity to estimate the allochthonous "contamination" of otherwise autochthonous sediments. These detrital sediments have $0.4 \% \mathrm{C}_{\text {org }}, 0.5 \% \mathrm{C}_{\text {inorg }}, 0.2 \%$ opal, and calcite/dolomite ratios of ca. 0.7 (Niessen, 1987). In comparison, L1 sediments are strongly enriched in the above components (generally by more than one order of magnitude: Tab. 1; Niessen, 1987; Niessen \& Kelts, 1989), indicating their dominantely autochthonous character in these Holocene sediments. Calcite in L 1 is generally more abundant than dolomite. Thus, for simplification, the overall low dolomite content (ca. $5 \%$ average; Niessen, 1987) is neglected in this study and the measured inorganic carbon is used to calculate the autochthonous calcite content. Also, allochthonous organic carbon is assumed to be minor and is here neglected (see also chapter 2). Thus all data in this paper presented as autochthonous compounds (equation 5) may be slightly overestimated due to a minor contamination by allochthonous materials.

Since abundances of living macro benthos in lakes are generally expressed as counts $\mathrm{m}^{-2}$ (e.g. characteristic for a specific year), we define Abundances of Benthic Fossils $(A B F)$ as a flux:

$$
A B F=C B F \cdot s
$$

with: $C B F=$ Counts of Benthic Fossils per volume wet sediment

\section{Results}

\subsection{Time intervals and pollen stratigraphy}

The 10000 year Holocene record of Lake Lugano is subdivided into eight time intervals (I to VIII) as summarized in Table 1 and Figure 3. Intervals II and I (L 1 a) cover the periods of initial and strong eutrophication after A.D. 1930 and A.D. 1970, respectively. The Intervals III to VIII differentiate the lithological units (L1 b and e) and/or correlate with the lithological boundaries (except for the boundary between L1c and L1b due to lack of datable organic matter). The different stratigraphic elements used in this study (lithological units, time intervals and pollen zones) are correlated in Figure 3.

The Holocene pollen record (Fig. 4) is characterized by Quercus and Alnus (the latter since the Subboreal, tree location up to an elevation of $1000 \mathrm{~m}$ a.s.1.), Abies and Fagus (mountain zone above $1000 \mathrm{~m}$ a.s. .), and Picea and Larix (subalpine area). At the beginning of the Subboreal (PAZ9, L1e-L1d transition), at about 3000 to $4000 \mathrm{BC}$, the fir forests disappeared very quickly from the Lake Lugano area and were completely replaced by beech forests. Within the oak forests Alnus became more important, and the areas of Carpinus and Ostrya began to expand.

The first cereal.pollen grains occur after ca. 1400 BC (PAZ12, Bronze Age, interval V), accompanied by indicators of pasture and agriculture, e.g. Poaceae, 


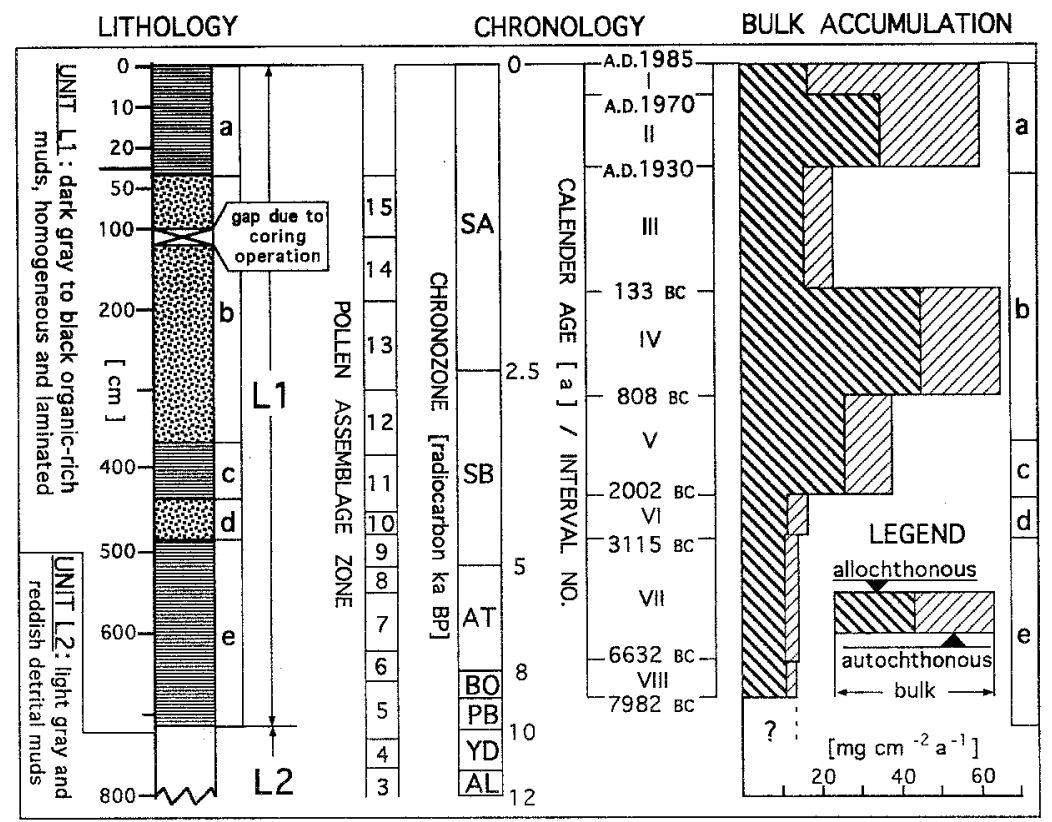

Figure 3. Stratigraphic overview and bulk accumulation of core LG 83/17.

Ericaceae, Plantago lanceolata, Rumex and Artemisia (Fig. 4). PAZ14 is characterized by the cultivation of Juglans, Castanea and Secale, which were introduced during Roman settlement (about $100 \mathrm{BC}$ ). In PAZ15 (interval III) cultural plants (Castanea, Juglans, cereals and Cannabis sativa) show maximal values. The pollen curves of Quercus and Alnus decrease and of herbaceous plants and heliophilous shrubs and trees, such as Juniperus, Cytisus scoparius, Ericaceae (mainly Calluna) and Populus, increase. The cultivation of Zea mays and Platanus orientalis since the 18 th century is indicated by pollen in PAZ16.

\subsection{Lacustrine accumulation rates}

The average bulk sediment accumulation rate (BSA) varied greatly during the Holocene (Fig. 3): it was minimal $\left(15 \mathrm{mg} \mathrm{cm}^{-2} \mathrm{a}^{-1}\right.$ ) prior to ca. $3000 \mathrm{BC}$ (L 1e, interval VII and VIII, Boreal to early Subboreal), increased gradually during intervals VI and V (L1d, c), and peaked around $500 \mathrm{BC}$ at $65 \mathrm{mg} \mathrm{cm}^{-2} \mathrm{a}^{-1}$ (L1 b, interval IV). Thereafter, during the Subatlantic period, BSA dropped back to $20 \mathrm{mg} \mathrm{cm}^{-2} \mathrm{a}^{-1}$ (L 1 b, III); a second major increase occurred to $60 \mathrm{mg} \mathrm{cm}^{-2} \mathrm{a}^{-1}$ during this century ( $\mathrm{L} 1 \mathrm{a}$, intervals I and II).

The Holocene accumulation of the autochthonous components (CSA, including organic matter, autoch thonous calcite and biogenic silica) followed the trend of BSA, showing a maximum in intervals IV and I (Fig. 3 and 5). The largest change is recorded for inorganic carbon, with rates below $0.2 \mathrm{mg} \mathrm{cm}^{-2} \mathrm{a}^{-1}$ prior to $3000 \mathrm{BC}$ 


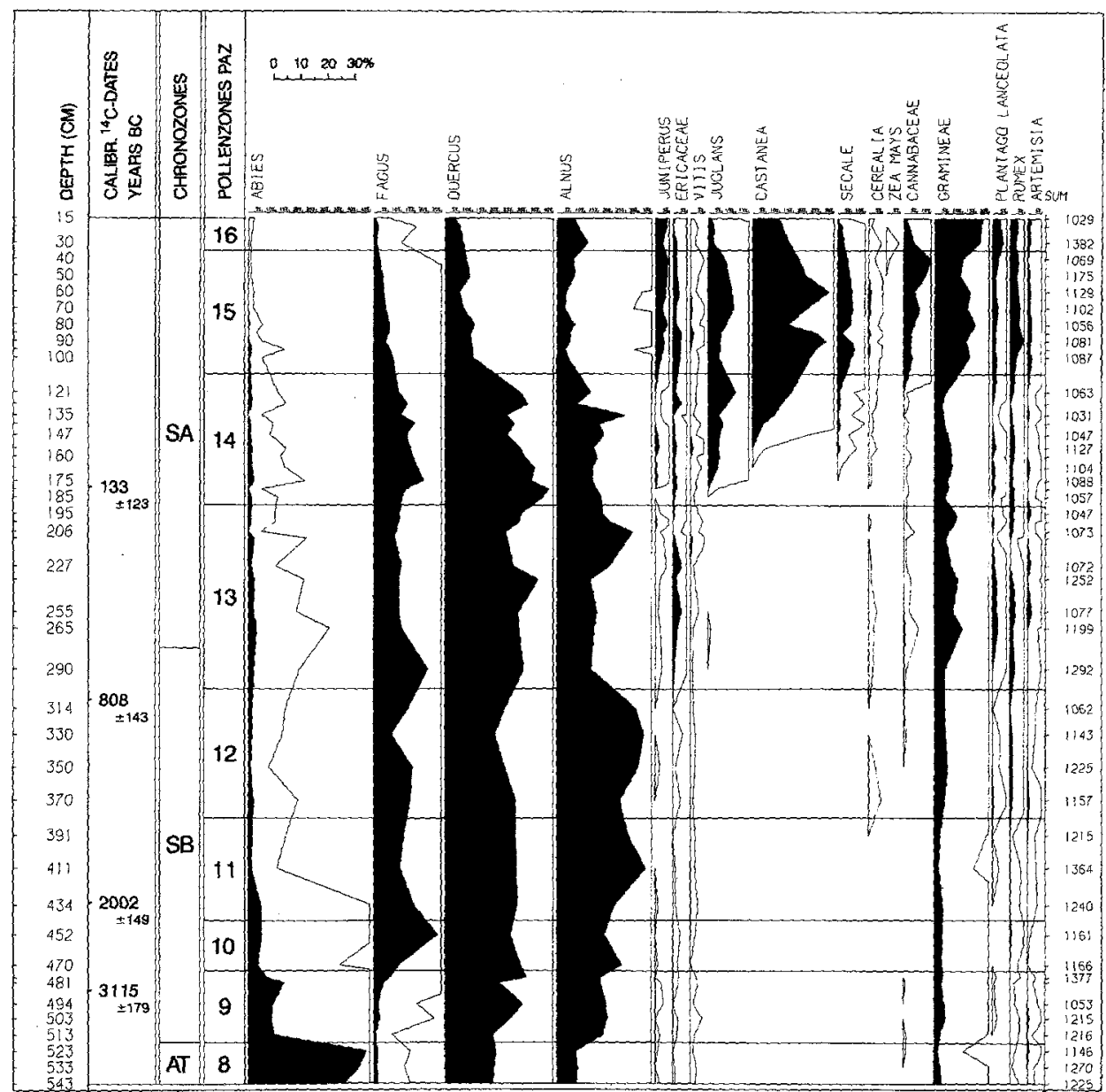

Figure 4. Major vegetation changes during the Holocene. Pollen results from LG 83/17 (PAZ 8 to 13 are from Wick, 1989; PAZ14 to 16 are from this study).

(intervals VII and VIII) as compared to $2.7 \mathrm{mg} \mathrm{cm}^{-2} \mathrm{a}^{-1}$ in interval I. Organic carbon has the lowest accumulation rates in $\mathrm{L} 1 \mathrm{e}$ (ca. $0.5 \mathrm{mg} \mathrm{cm}^{-2} \mathrm{a}^{-1}$ in VII and VIII) despite the relatively high content in bulk sediments $(2-5 \%$, Fig. 3$)$ as compared to $4 \mathrm{mg} \mathrm{cm}^{-2} \mathrm{a}^{-1}$ or $7 \%$ in interval I. Biogenic silica reached accumulation rates during interval IV (early Subatlantic) similar to those of today (interval I). On the other band, the increase of biogenic silica from interval III to I (eutrophication period after A.D. 1930) is relatively small ( 8 to $12 \mathrm{mg} \mathrm{cm}^{-2} \mathrm{a}^{-1}$ ) as compared to the doubling of the carbon accumulation (Fig. 3).

The total autochthonous accumulation, calculated by combining equations (4) and (5), accounts for about $70 \%$ of the bulk accumulation in sub-unit L $1 \mathrm{a}$ and less than $40 \%$ in $\mathrm{L} 1 \mathrm{~b}$ to $\mathrm{L} 1 \mathrm{e}$ (Fig. 3). By comparing autochthonous accumulation with BSA (Fig. 3) it becomes evident that the first peak of BSA during interval IV is related 

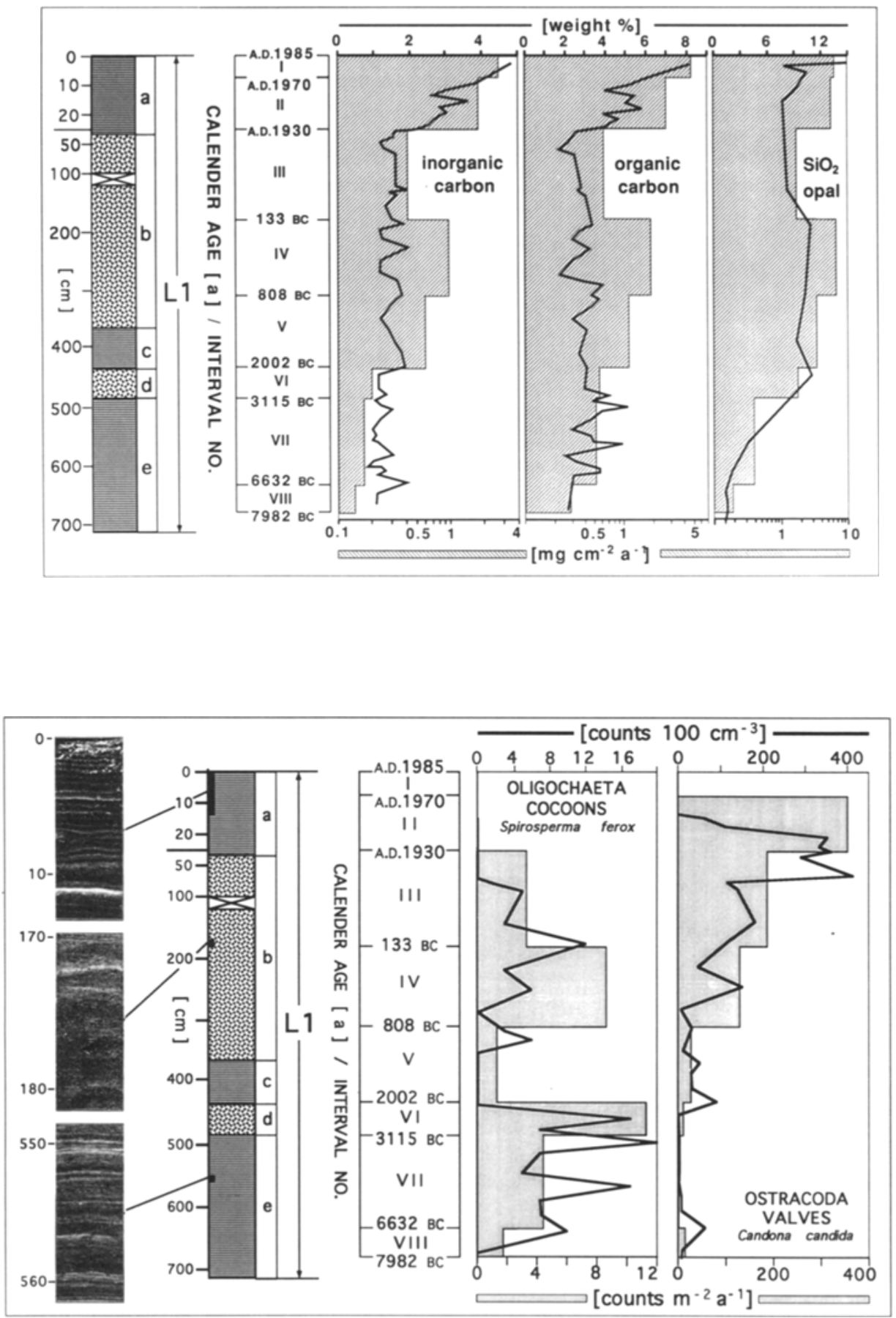


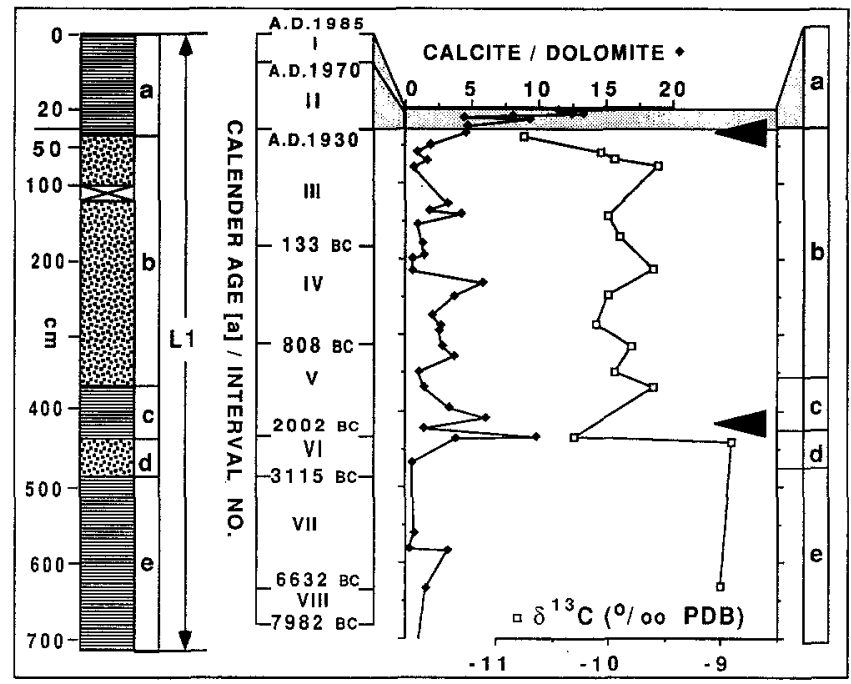

Figure 7. Core LG 83/17. Calcite/dolomite ratios compared to stable carbon-isotope values (redrawn after Niessen, 1987). Arrows mark time intervals with accelerated aquatic carbon cycle activity.

to an increase in both allochthonous and autochthonous sedimentation, whereas the second maximum (I and II) is entirely derived from an increase in autochthonous sedimentation.

\subsection{Abundances of benthic remains}

Fossils of bottom dwellers (ostracod valves of Candona candida, and/or oligochaete cocoons typical of Spirosperma ferox) are present in all of the Holocene subunits except in the uppermost part of unit L 1 a (interval I), which is free of benthic fossils (Fig. 6). Oligochaete remains show generally low abundances (about 1 to 4 cocoons $\mathrm{m}^{-2} \mathrm{a}^{-1}$ equation (6)) or are absent in sediment sections with more distinct laminations (sub-units L 1a, L 1 c and parts of L 1 e; Fig. 6). In laminated sub-units L1 a (interval II) and L 1c (V) there are no fossils of Spirosperma ferox, but Candona candida is present (Fig. 6). The abundance of ostracod-valves show a generally increased trend, together with the autochthonous accumulation rates, particularly with respect to inorganic carbon (Fig. 5 and 6).

\section{Discussion and conclusions}

\subsection{Primary production}

In lakes, fluxes of organic carbon (plankton remains) and opal (biogenic silica of diatom frustules) may be related to primary production (e.g. Hollander, 1989; 
Schelske et al., 1987; respectively). Fluxes of inorganic carbon (calcite) are indirectly related to productivity. Surface-water $\mathrm{CO}_{2}$ assimilation changes chemical equilibria which leads to supersaturation with respect to $\mathrm{CaCO}_{3}$ and subsequently to precipitation (e.g. Kelts \& Hsü, 1978).

In order to reconstruct lacustrine primary production from the geological record, one has to take into account that the accumulation of autochthonous components, particularly organic carbon, is affected by the degree of preservation. In Lake Lugano, microbial metabolism is observed in the hypolimnion and in the top $30 \mathrm{~cm}$ of the sediment column (Lazaretti et al., this issue), so part of the seston is oxidized. Under eutrophic conditions, oxygen is commonly consumed within the top few millimeters of the sediments or in the water column of the hypolimnion (see discussion in Lazaretti et al., this issue). Therefore, if renewal of deep-water oxygen is sufficient, decreased sediment deposition (lower production) is generally coupled with a reduction in organic matter preservation resulting from longer exposure at the oxic sediment/water interface (Bralower \& Thierstein, 1987). In many organic rich sediments, however, there is an excess of oxidizable organic matter over electron acceptors, so microbial metabolism does not destroy the direct relationship between production and burial of organic carbon (Pedersen \& Calvert, 1990). This is particularly important for lacustrine environments because the low $\mathrm{SO}_{4}$ content of freshwater systems limits the organic-matter oxidizing capacity of microbial sulfate reduction (Kelts, 1988).

The sensitivity of organic/inorganic carbon and biogenic silica to changes in primary production in Lake Lugano can be tested using the sediments which were deposited during the last six decades of eutrophication. Accumulation of inorganic and organic carbon, and to a less extent of biogenic silica, increase by a factor of 1.5 to 2 from interval II (A.D. 1930-1970) to interval I (A.D. 1970-1985, Fig. 5). This increase correlated with a doubling of $\mathrm{PO}_{4}$ in the lake water according to measurements in 1964 and after 1980 (during winter overturn; Jaag \& Märki, 1968; Barbieri \& Martini, 1982; respectively). Primary production has only been measured in Lake Lugano since 1980 (Rufli, 1982; $460 \mathrm{~g} \mathrm{C} \mathrm{m}^{-2} \mathrm{a}^{-1}$ ). Moreover, sediments deposited during this century show an increase of organic carbon which is in positive correlation to that of autochthonous calcite. This relationship exists in all profundal areas of Lake Lugano regardless of water depth and local sedimentation rates (Fig. 1, 8 ). We therefore prefer to explain the gradient of organic carbon by increasing flux rates during eutrophication rather than by a down-core trend of degradation. A similar conclusion was drawn from an increase in sedimentary pigments in the Lake Lugano basin of Ponte Tresa (Züllig, 1982).

The accumulation of opal can be expected to behave similarly to that of carbon, as the preservation of $\mathrm{SiO}_{2 \text { diatom }}$ in sediments of $\mathrm{pH}$-buffered systems is also largerly controlled by the flux of diatoms (or other silicious algae) through the water column and thus production (e.g. Pokras, 1986). Likewise a sediment core from the basin of Ponte Tresa (Lake Lugano) revealed a steady increase of diatom frustules parallel to that of total pigments between A.D. 1900 and 1978 (Züllig, 1982). Under conditions of very high productivity (e.g. Lake Lugano after A.D. 1980), however, formation of biogenic silica may be limited by depletion of the dissolved silica reservoir in the water (Schelske et al., 1987) or by competition of silicious algae with other species (Polli \& 

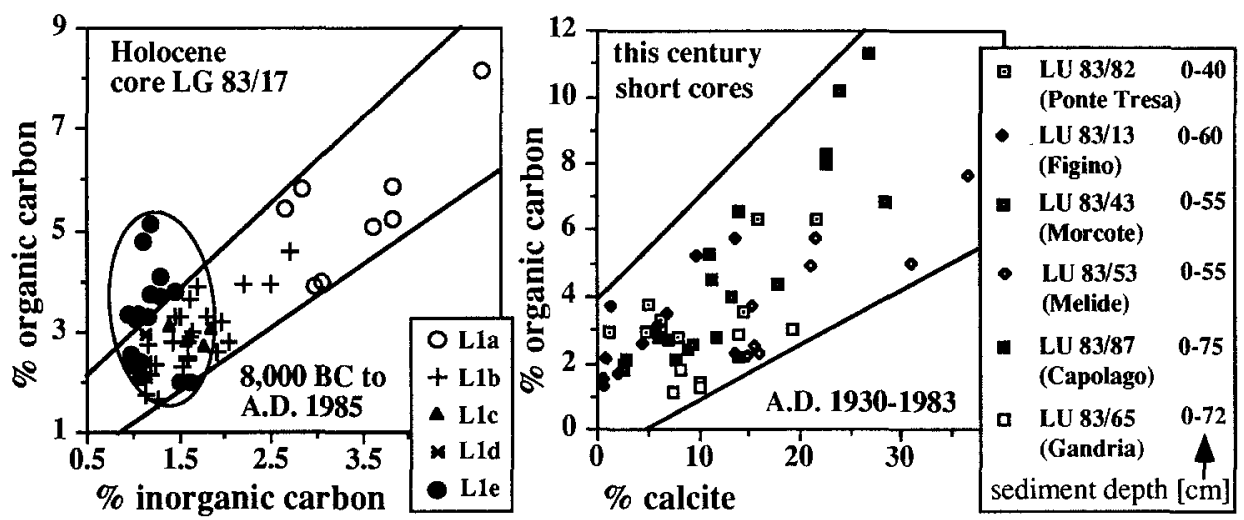

Figure 8. Organic carbon versus inorganic carbon and calcite, respectively. Left: Holocene data from core LG 83/17 (Fig. 5). Note the high organic carbon to inorganic carbon content in unit L1e. Right: Last 100 years (eutrophication record), cores from different basins of Lake Lugano (core locations in Fig. 1, data from Geologisches Institut, ETHZ, 1984). The correlation coefficients range from 0.71 (Ponte Tresa) to 0.79 (Morcote).

Simona, this issue). This could explain the disproportionately low increase in opal accumulation in L 1 a compared to the other autothonous compounds (Fig. 5).

One further argument for combining biogenic silica and carbon is the different chemical control on their preservation. For example, the preservation of organic carbon could have been different in the past due to very high respiration rates in the hypolimnion and subsequently dissolution of calcite due to lower $\mathrm{pH}$ values. Low carbon accumulation could then be misinterpreted as being related to low primary production. Lower $\mathrm{pH}$ values, however, would have a positive effect on the preservation of biogenic silica. Consequently if changes in preservation controlled the record at any time in the past, the accumulation of carbon and opal should shift in different directions. This is not observed in the Holocene record of Lake Lugano; all autochthonous compounds show covariant shifts (Fig. 5). Thus the effect of preservation on accumulation rates of carbon and biogenic silica is assumed to be minor relative to that of production, and the accumulation of their autochthonous compounds is used as a proxy for past production.

The extremely low accumulation rates of opal, organic carbon and inorganic carbon in unit L $1 \mathrm{e}$ would suggest a past production of not more than $10 \%$ of the present level for the early Holocene (Boreal and Atlantic, VIII and VII, respectively). A first significant increase in productivity is indicated for the time interval between 3000 and $2000 \mathrm{BC}$ by the accumulation of carbon (organic and inorganic) to about $30 \%$ and of biogenic silica of up to $100 \%$ of the rates observed for this century (after A.D. 1930-1985). Thereafter the productivity may have dropped back to about $20 \%$ of the present level until the recent onset of eutrophication. The interpretation of the Holocene productivity of Lake Lugano is summarized in Figure 9. The trend is also consistent with that of total pigment accumulation assessed by Niessen (1987) for the Holocene sediments of core LG 83/15 (Fig. 1, 2), which increased from ca. 0.3 to $1.8 \mu \mathrm{g} \mathrm{cm}^{-2} \mathrm{a}^{-1}$ in mid Holocene time and then to $25 \mu \mathrm{g} \mathrm{cm}^{-2} \mathrm{a}^{-1}$ during the last few decades. 

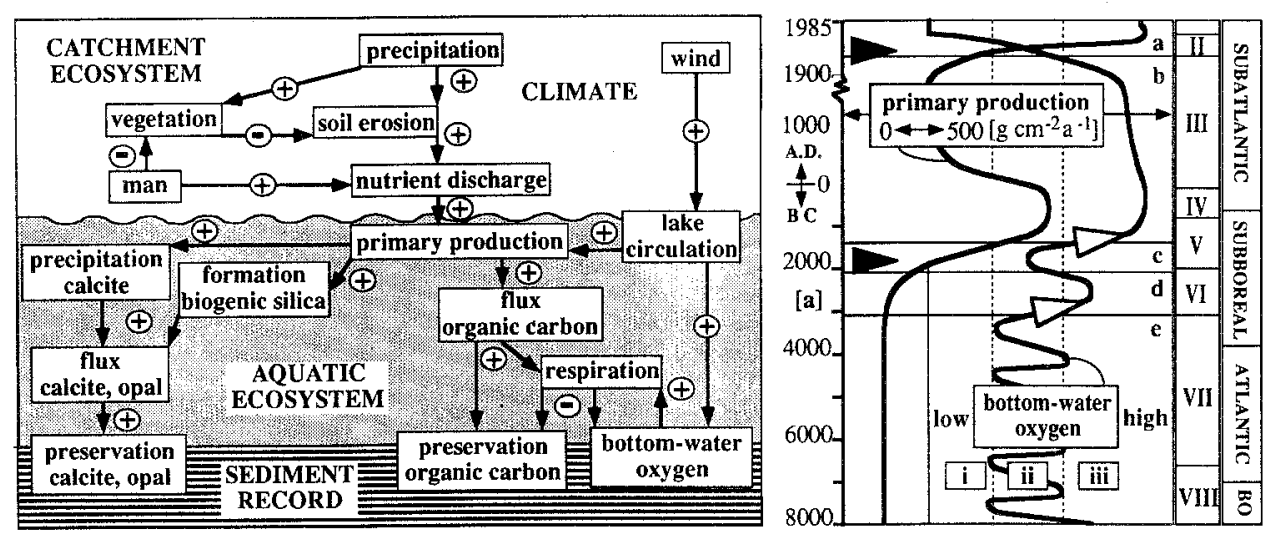

Figure 9. Left: Flow diagram showing major factors controlling the formation, deposition and preservation of autochthonous sediments in Lake Lugano as interpreted in the text (temperature effects not considered)

Right: Interpretation of productivity and bottom-water oxygen status for the Holocene of Lake Lugano (southern basin). Productivity assessment is based on accumulation rates of organic carbon, inorganic carbon (calcite), and biogenic silica (Fig. 5). Categories (i), (ii), and (iii) for bottom-water oxygen are explainéd in the text. White arrows mark periods with proposed increases in lake circulation (oxygen injection into deep water). Black arrows mark times with acceleration of the aquatic carbon cycle

In conclusion, high burial rates of organic carbon $\left(5 \mathrm{mg} \mathrm{cm}^{-2} \mathrm{a}^{-1}\right)$ are clearly related to eutrophication (intervals I and II). Therefore, laminated sediment sections characterized by minimum accumulation rates of autothonous sediments (in particular L1e, VII and VIII) are not related to high primary production. On the other hand, the formation of organic carbon-rich sediments in Lake Lugano is not due entirely to high productivity. Apparently an increased organic carbon content (above Holocene average of $3 \%$ ) characterized periods of both very high (I and II) and very low production (intervals VI and VII). The latter indicates that the early Holocene deep-water environment of Lake Lugano (southern basin) might have been particularly supportive for organic carbon preservation, despite the low flux rate.

\subsection{Bottom water oxygen}

Evidence from the Lake Lugano sediment record which can be related to past bottomwater oxygen conditions includes fossils of specific benthic ostracod and oligochaete species (Candona candida and Spirosperma ferox, respectively; Fig. 6) and the sedimentary fabric (preservation of laminae). The use of oligochaete cocoons in particular is a relatively new field in palaeolimnology (Bonacina et al., 1986), whereas the latter has repeatedly been used to characterize bioturbation and related bottom water oxygen levels in organic-rich marine environments (Rhoads \& Morse, 1971; Rosenberg, 1977). Anaerobic marine environments are characterized by welllaminated sediments, whereas most sediments within dysaerobic and aerobic realms are homogenized by bioturbation (Savrda et al., 1984). 
There are no comprehensive trace-fossil models for assessing profundal oxygen content in lakes. Neither is there a strict rule that anoxic bottom-water conditions always lead to laminated lacustrine sediments. However seasonal sedimentation pulses of autochthonous calcite and organic matter are often preserved in varves if the bottom water is anoxic, as is the case in Lake Lugano today and in many other meromictic and/or eutrophic lakes (e.g. Niessen \& Sturm, 1987; Lotter, 1989). Thinsections of massive sediments of unit $\mathrm{L} 1 \mathrm{~b}$ show in places nearly homogenized relicts of calcite and diatom laminae (Niessen, 1987). This suggests that distinct seasonal sediment pulses occurred in the past which would probably be preserved as laminae if not largely destroyed after deposition by burrowing organisms. If this assumption is valid, laminated sections should have less benthic fossils than massive sections, which generally holds true when compared with the abundances of oligochaete cocoons in the Holocene units L 1 a to d (Fig. 6).

The presence of Candona candida and Spirosperma ferox-remains is an indication of dysaerobic or aerobic conditions at the sediment-water interface. Oligochaetes are particularly used as indices of lake pollution (Lauritzen et al., 1985; Probst, 1987). Profundal species are disproportionately low in organic-rich sediments if deep-water oxygen is depleted (Lang, 1984). For example, in the sediments of Lake Geneva abundances of Spirosperma ferox decreased to zero during eutrophication between A.D. 1982 and 1985 (Lang, 1986). Bonacina et al. (1986) have linked the decrease of Spirosperma ferox cocoons in the sedimentary record of Lake Orta with an increase in pollution.

In Lake Lugano palaeo-oxygen indicators in the topmost part of core LG 83/17 can be compared with past oxygen measurements in the lake. Cocoons of Spirosperma ferox disappear just below the onset of laminations at the L $1 \mathrm{a} / \mathrm{L} 1 \mathrm{~b}$ boundary (A.D. 1930). Valves of Candona candida are found in sediments deposited until about A.D. 1966 (Niessen, 1987; Tab. 1). Accordingly, the hypolimnic oxygen content of Lake Lugano has decreased by about $3 \mathrm{mg} / \mathrm{l}$ between 1946 and 1981 as shown by a data compilation of Peduzzi (1981). Oxygen contents of below $0.2 \mathrm{mg} / 1$ were observed since 1964 for the deep water of the southern basin (Jaag \& Märki, 1968). Thus the observed sedimentary trend correlates with the decrease in bottom water oxygen content during eutrophication. It also implies that the benthic remains represent in situ profundal conditions and are not transported from shallower areas of the lake. Apparently Candona candida is more resistant to low oxygen concentrations than is Spirosperma ferox.

Based on the above comparison between the sedimentary and the instrumental record, three categories are suggested to interpret the bottom water history of Lake Lugano (Fig. 9):

(i) Distinctly laminated sediments and the absence of macrobenthic fossils indicate seasonally to perennially anaerobic conditions at the sediment water interface. This occurred only under eutrophic conditions after A.D. 1966 (interval I).

(ii) Laminated sediments, the presence of Candona candida valves and absence of Spirosperma ferox cocoons indicate perennially aerobic conditions with relatively low oxygen concentrations. This occurred twice in Lake Lugano, in interval II (L 1 a, prior to A.D. 1966) and in interval V (L1 c, mid Subboreal), and is in both cases associated with indications for increased production. 
(iii) Homogeneous (most likely bioturbated) sediments, the presence of Candona candida valves and relatively high abundances of Spirosperma ferox cocoons indicate well oxygenated profundal conditions. This occurred during the early Subboreal (L $1 \mathrm{~d}$, interval VI), when production was supposed to be low. It is also characteristic for most of the Subatlantic of Lake Lugano (L1b, interval IV and III), when we believe production increased.

The early Holocene history of Lake Lugano (L1e), however, does not fit exactly into one of the above categories. The preservation of distinct laminations in places suggests a low abundance or absence of burrowing organisms which, for organic rich sediments, one would interpret as indicative of dysaerobic or anaerobic conditions. This interpretation is supported by the relatively high ratio of organic to inorganic carbon in L 1 e (Fig. 8), suggesting better preservation of organic matter relative to calcite during the early Holocene. On the other hand, the presence of Spirosperma ferox cocoons in $L 1 \mathrm{e}$ (Fig. 6) does indicate oxygenated bottom water conditions. To explain this, we suggest a scenario in which the lake bottom might have been well oxygenated over periods of some years or decades, followed by periods with a diminished oxygen content at the sediment water interface. Indeed, Niessen (1987) described short periods with distinct microlamination in L 1 e comprising about 20 to 30 thin couplets (varves?) intercalated with more massive sediments. Since the sedimentation rate (and time-resolution) is very low in L 1e, sub-samples used for counting of benthic remains cover relatively large time windows (e.g. 100 years) and thus integrate over several short-term shifts. This could explain why cocoons were found in all samples analyzed by Niessen (1987). The L 1 e sediments may be similar to partially bioturbated sediment fabric types observed in marine environments which are produced by short-term migration of the dysarobic-anaerobic boundary in the water column (Savrda et al., 1984). However, further detailed studies are necessary for organic rich lacustrine sediments, both laminated and non-laminated, to test our hypotheses. The low abundance of ostracod valves in $\mathrm{L} 1 \mathrm{e}$ is possibly related to other factors besides bottom water oxygen (e.g. insufficient carbonate buffering due to extremely low rates of calcite deposition, Fig. 5).

In conclusion, the organic carbon rich Holocene sediments of Lake Lugano were generally deposited under aerobic and dysaerobic conditions in which bottom water oxygen was apparently not always negatively correlated with productivity: Oxygen levels were probably low relative to lake production during the Boreal and Atlantic (L 1 e, VII and VIII), and relatively high during the early Subatlantic (L 1 b, IV). The former conditions result in slightly higher (up to $5 \%$ ) organic carbon contents as compared to the latter (up to $4 \%$, Fig. 5). Higher organic carbon contents (more than $8 \%$ ) formed only under conditions of high production and seasonal profundal anoxia, as has occurred during the eutrophication of this century.

\subsection{The influence of climate and man on Lake Lugano's history}

The processes controlling the oxygen budget at the sediment/water interface are oxygenation during lake circulation and oxygen consumption during mineralisation of organic matter (Fig. 9). A comparison of the interpreted bottom water oxygen content and productivity conditions in Lake Lugano during the Holocene indicates 
that the intensity of these two processes has varied with time. Prior to about $3000 \mathrm{BC}$, sediment laminations were well preserved and organic carbon content was high despite low organic matter flux rates. These characteristics could be explained if the supply of oxygen to the lake bottom was lower than that for the last 3500 years. Oxygen gradients at the sediment-water interface are influenced by the intensity of vertical mixing of water during isothermal (winter) conditions. Mixing can be reduced by a salinity stratification in deep water and/or by lack of wind energy at the lake surface. The first leads to a self-stabilization of stratification and can result in long-term hypolimnic anoxia, as is the case for the northern basin of Lake Lugano today (Wüest et al., this issue). Since long-term anoxia is not indicated by the benthic fossil record for the southern basin, periodic lack of wind energy is proposed to explain the dysaerobic or anaerobic profundal conditions during phases of the early Holocene. This may suggest reduced wind intensity on a local or regional scale during the "climate optimum", which then increased to conditions similar to the present during the Subboreal (Fig. 9). The latter change must have been significant at the L 1 c/d-boundary (ca. $1400 \mathrm{BC}$ ) since oligochaete abundances (and possibly bioturbation) increased, despite evidence for a further rise in production at that time.

If climate had a significant influence on the bottom water oxygen content in Lake Lugano, what then controlled the proposed changes in primary production? The increase of autochthonous accumulation during the late Holocene is coupled with higher input rates of sediments from allochthonous sources, indicating increased catchment erosion, because BSA has more than doubled after $3000 \mathrm{BC}$, but only about $30-40 \%$ of BSA is related to autochthonous sedimentation (Fig. 3). Moreover, Niessen (1987) has shwon in core LG 83/17, that the increase of allochthonous sedimentation is positively correlated with the accumulation of the cosmogenic isotope ${ }^{10} \mathrm{Be}$ (half-life $1.5 \times 10^{6}$ a) which reached accumulation rates in the lake of up to 20 -fold the mean atmospheric flux rate of ${ }^{10} \mathrm{Be}$. He concluded that the rise of allochthonous input was mainly derived from soils since storage and release of ${ }^{10} \mathrm{Be}$ in terrestrial environments is strongly associated with soil formation and erosion, respectively (Brown et al., 1981; Pavich et al., 1985). Soil erosion was probably minor during the early Holocene, as mirrored by minimum BSA in the lake basin (Fig. 3). During this period the catchment was more densely forested than at any other time in the Holocene (Wick, 1989; Fig. 4). Higher terrestrial plants are an effective "pump" of phosphorus from the lithosphere to the pedosphere (Meybeck, 1982). We suggest that soil phosphorus was enriched during the early Holocene until $3000 \mathrm{BC}$. Nutrient release to the lake was minimal. After $3000 \mathrm{BC}$, soils and the nutrients they contained were eroded at an increased rate into the aquatic system. The lake organic matter production subsequently increased (Fig. 9). Allochthonous input was most severe between 800 and $100 \mathrm{BC}$ (Fig. 3) when lake productivity may have reached $50 \%$ of its present value (Fig. 9). During the last few decades allochthonous and autochthonous sedimentation fail to correlate because of an increased input of nutrients derived from fertilizers and sewage.

According to the above scenario, a two-fold acceleration of the aquatic carbon cycle should be expected (increase in production, respiration and burial of organic matter) during the Subboreal and during this century (Fig. 7 and 9). Indeed shifts are mirrored by inorganic carbon produced in the epilimnion (autochthonous calcite) 
and at the lake bottom (ostracod valves) as shown by Niessen (1987). Both transitions from intervals VI to V and III to II show evidence for increased production by a sharp increase of autochthonous calcite over allochthonous dolomite (Fig. 7). Correspondingly, the stable isotope composition of benthic ostracod valves shifted to more negative $\delta{ }^{13} \mathrm{C}$ values. Increased profundal respiration of organic matter (coupled with a decrease of dissolved oxygen at the lake bottom, as indicated by the disappearance of oligochaete remains as well as the preservation of lamination at the onsets of $\mathrm{L} 1 \mathrm{c}$ and $\mathrm{L} 1 \mathrm{a}$ ) leads to an enrichment of ${ }^{12} \mathrm{C}$ in the dissolved deep-water carbon reservoirs (e.g. McKenzie, 1985) which is used by ostracods to build their valves (e.g. Lister, 1988).

The causes of the mid Holocene increase in erosion and subsequent impact on the aquatic system is difficult to assess, however. Erosion can be directly related to greater precipitation and/or to a decrease in vegetation cover (Fig. 9). The latter is likely to be affected by human changes during the Neolithic period (ca. $4000 \mathrm{BC}$ ). In pollen diagrams from several small lakes near Lake Lugano, the Neolithic period is marked by deforestation and cultivation of cereals at the beginning of the Subboreal (Zoller, 1960; Schneider, 1978; Schneider \& Tobolski, 1985), whereas human impact on the Quercus-Alnus forests at Lake Lugano was probably very limited, and not the only reason for the increase in soil erosion. Possibly the vegetation changes in the upper regions of the catchment area (1000-2000 m a.s.1.) had an influence on the sedimentation in the lake. Abies disappeared from at the beginning of the Subboreal and was replaced by Fagus. The reason for this change, which was limited to the mountain forests of the Lake Lugano area, are not known (Wick, 1989; Zoller, 1960). At the same time the Alpine treeline decreased due to human impact and/or climate change (Lang, in press; Wick, 1991). Thus the initial phase of increased soil erosion in Lake Lugano is indeed synchronous with vegetation changes.

During the Bronze Age (PAZ 12) human impact on the vegetation increased. In the Iron Age (PAZ13) the forests (mainly of Alnus) were thinned considerably (Fig. 4) in order to develop pastures and grain fields. Thus the marked peak in alloch thonous sediment accumulation in Lake Lugano after 800 BC (interval IV) can also be related to a strong increase in soil erosion caused by human activity.

The beginning of the most dramatic human impact on the natural vegetation, however, dates to the early Middle Ages (ca. A.D. 450-500). Alnus-Quercus forests were largely destroyed, and the cultivation of Castanea, Juglans, cereals and Cannabis sativa became very important. High percentages of grasses, Plantago lanceolata, Juniperus, Calluna and other shrubs (Fig. 4) suggest rather intensive grazing (probably also in the forests) from the Middle Ages to recent time. Although one would expect another increase in soil erosion resulting from this intensive anthropogenic use of the landscape, these hinterland changes are neither reflected by the BSA nor by any of the productivity indicators during interval III. Since the exact time resolution of interval III is relatively poor (large radiocarbon time window from $808 \mathrm{BC}$ to A.D. 1930 , including a core gap of ca. $20 \mathrm{~cm}$ ) compared to the drastic human-induced vegetation changes at this time, it is too early to draw conclusions about the aquatic response to certain points during this period. This will require a complete core recovery, a denser net of palaeolimnological data as well as more radiocarbon dating for the last two millennia of the record. 
In conclusion, the case study from Lake Lugano suggests that the increased input of terrestrial particulate matter (mostly soil) caused an acceleration of the aquatic carbon cycle. This suggests that, under mid latitude semi-humid climate conditions, terrestrial environments may release nutrients roughly proportional to the total detrital discharge from soil-covered terrain which in turn controls aquatic productivity. Mid-Holocene changes in catchment erosion are coupled with major shifts in the vegetation, caused by climatic change and/or human impact. Climatic changes may also be responsible for a proposed increase of winter turn-over rates injecting more oxygen into the deep water environment of Lake Lugano after the end of the Atlantic chronozone.

\section{ACKNOWLEDGEMENTS}

The research was financed by the Swiss National Foundation (NF-project 2.420.075) and by a contribution from the Canton of Ticino (Dipartimento Ambiente). We are grateful to G. Bonomi (University of Bologna) for his help in identifying the oligochaete cocoons as well as K.J.Hsü, K. Kelts, B. Ammann, and H. Lang for their support for the projects and for many helpful discussions. We thank our colleagues H. Weissert, T. Hawthorne, G. Lister, and two anonymous reviewers for their critical and stimulating comments on the results and on earlier drafts of the manuscript.

\section{REFERENCES}

Barbieri, A. and Martini, L.: Caratteristiche, fisiche e chimiche delle acque lacustri. In: Peduzzi, R. (Ed.): Studio sull'entrofizzazione del Lago di Lugano. Rapporti Commissione Internazionale per la protezione delle acque italo-svizzere, Campagna 1982, 31-40 (1982).

Berner, R. A.: Principles of Chemical Sedimentology. McGraw-Hill, New York, 240 pp (1971).

Bonacina, C., Bonomi, G. and Monti, C.: Oligochaete cocoon remains as evidence of past lake pollution. - Hydrobiologia, 143:395-400 (1986).

Bralower, T. J. and Thierstein, H. R.: Organic carbon and metal accumulation rates in Holocene and mid-Cretaceous sediments: palaeoceanographic significance. In: Brooks, J. \& Fleet, A. J. (Eds.): Marine Petroleum Source Rocks. Geological Society Special Publication, 26, 345-369 (1987).

Brown, L., Sacks, I. S., Tera, F., Klein, J. and Middleton, R.: Beryllium-10 in continental sediments. - Earth Planet. Sci. Lett., 55, 370-376 (1981).

Demaison, G. J. and Moore, G. T.: Anoxic environments and oil source bed genesis. Organic Geochemistry, 2, 9-31 (1980).

Geologisches Institut der ETHZ: Sedimentologische Untersuchungen im Luganersee. Bericht zu Handen des Kanton Tessin (Dipartimento Ambiente), unpublished, 25 pp (1984).

Hollander, D. J.: Carbon and Nitrogen Isotopic Cycling and Organic Geochemistry of Eutrophic Lake Greifen: Implications for Preservation and Accumulation of Ancient Organic Carbon-Rich Sediments. Mitt. Geol. Inst. ETH und Universität Zürich, Neue Folge, 279, 317 pp (1989).

Jaag, O. and Märki, E.: Die neuere Entwicklung und der derzeitige Zustand der schweizerischitalienischen Grenzgewässer. Wasser- und Energiew. 60, 234-247 (1968).

Kelts, K.: Environments of deposition of lacustrine petroleum source rocks: an introduction. - In: Fleet, A. J., Kelts, K. and Talbot, M. R. (Eds.): Lacustrine Petroleum Source Rocks. Geological Society Special Publication, 40, 3-26, London (1988).

Kelts, K. \& Hsü, K. J.: Freshwater Carbonate Sedimentation. - In: Lerman (Ed.): Lakes. Springer, New York, 295-323 (1978).

Lang, C.: Eutrophication of Lakes Léman and Neuchâtel (Switzerland) indicated by oligochaete communities. Hydrobiologia 115, 131-138 (1984). 
Lang, C.: Eutrophisation du Léman indiquée par les communautés d'oligochètes: campagnes 19821985. Schweiz. Z. Hydrol. 48/2, 230-239 (1986).

Lang, G.: Holozäne Veränderungen der Waldgrenze in den Schweizer Alpen - Methodische Ansätze und gegenwärtiger Kenntnisstand. Diss. Bot. (in press).

Lauritsen, D. D., Mozley, S. C. and White, D. S.: Distribution of oligochaetes in Lake Michigan and comments on their use as indices of pollution. J. Great Lakes Res. 11(1), 67-76 (1985).

Linik, Suess, Becker, Stuiver, Kromer, Ferguson, Rhein, Schoch, Munnich and Loxx: Average Dataset of LSB, SKBF, KRBSMSB/20 years steps. Radiocarbon, 28(2B), 805-1021 (1986).

Lister, G. S.: Lithostratigraphy of Zübo sediments. Contr. Sedimentology, 13, $31-58$ (1984).

Lister, G. S.: Stable isotopes from lacustrine Ostracoda as tracers for continental palaeoenvironments. In: De Deckker, P., Colin J.-P. \& Peypouquet J.-P. (eds) Ostracoda in Earth Sciences. Elsevier, 201-218 (1988).

Lotter, A. F.: Evidence of annual layering in Holocene sediments of Soppensee, Switzerland. Aquatic Sciences 51/1, 19-30 (1989).

McKenzie, J. A.: Carbon isotopes and productivity in the lacustrine and marine environment. In: Stumm, W (Ed.): Chemical processes in lakes. John Wiley, New York, 99-117 (1985).

Meybeck, M.: Carbon, nitrogen, and phosphorus transport by world rivers. Am. J. Science 282, $401-$ 450 (1982).

Niessen, F. and Sturm, M.: Die Sedimente des Baldeggersees (Schweiz). - Ablagerungsraum und Eutrophierungsentwicklung während der letzten 100 Jahre. - Arch. Hydrobiol. 108(3), 365-383 (1987).

Niessen, F.: Sedimentologische, geophysikalische und geochemische Untersuchungen zur Entstehung und Ablagerungsgeschichte des Luganersees (Schweiz). Mitt. Geol. Inst. Eidg. Technische Hochschule und der Universität Zürich, Neue Folge 268, 332 pp (1987).

Niessen, F. and K. Kelts: The deglaciation and Holocene sedimentary evolution of southern perialpine Lake Lugano - implications for Alpine paleoclimate. Eclogae geol. Helv. 82/1, 235236 (1989).

Niessen, F.: Die Sedimente des Luganersees: Chronik wechselnder Einflüsse von Klima und Mensch. Proceedings International Symposium "Limnological Aspects and Management of the Lake of Lugano". Laboratorio Studi Ambientali, Dipartimento Ambiente, Bellinzona, 1-12 (1990).

Pavich, M. J., L. Brown, J. N. Valette-Silver, J. Klein and R. Middleton; ${ }^{10} \mathrm{Be}$ analysis of a Quarternary weathering profile in the Virginia Piedmont. Geology 13(1), 39-41 (1985).

Pedersen, T. F. and S. E. Calvert: Anoxia vs. Productivity: What Controls the Formation of OrganicRich Sediments and Sedimentary Rocks? The American Association of Petroleum Geologists Bulletin 74(4), 454-466 (1990).

Peduzzi, R.: Discussione e conclusioni. In: R. Peduzzi (Ed.): Studio sull'eutrofizzazione del Lago di Lugano. Rapporti Commissione Internazionale per la protezione delle acque italo-svizzere, Campagna 1981, 75-84 (1981).

Pokras, E. M.: Preservation of fossil diatoms in Atlantic sediment cores: control by supply rate. Deep-Sea Res. 33(7), 893-902 (1986).

Probst, L.: Sublittoral and profundal Oligochaeta fauna of Lake Constance (Bodensee-Obersee). Hydrobiologia 155, 277-282 (1987).

Rhoads, D. C. \& J. W. Morse: Evolutionary and ecologic significance of oxygen-deficient marine basins. Lethaia 4, 413-428 (1971).

Rufli, H.: Produzione Primaria. In: R. Peduzzi (Ed.) Studio sull'eutrofizzazione del Lago di Lugano. Rapporti Commissione Internazionale per la protezione delle acque italo-svizzere, Campagna 1981, 59-61 (1982).

Rosenberg, R.: Benthic macrofaunal dynamics, production and dispersion on an oxygen - deficient estuary of west Sweden. J. Exp. Mar. Biol. Ecol. 26, 107-133 (1977).

Savrda, C. E., D. J. Bottjer and D. S. Gorsline: Development of a comprehensive oxygen-deficient marine biofacies model: Evidence from Santa Monica, San Pedro, and Santa Barbara Basins, California continental borderland. The American Association of Petroleum Geologists Bulletin 68, 1179-1192 (1984).

Schelske, C. L., H. Züllig and M. Boucherle: Limnological investigation of biogenic silica sedimentation and silica biogeochemistry in Lake St. Moritz and Lake Zürich. Schweiz. Z. Hydrol. 49/1, 42-50 (1987). 
Schneider, R.: Pollenanalytische Untersuchungen zur Kenntnis der spät- und postglazialen Vegetationsgeschichte am Südrand der Alpen zwischen Turin und Varese (Italien). Bot. Jb. Syst. 100, 26-109 (1978).

Schneider, R. and K. Tobolski: Lago di Ganna - Late-Glacial and Holocene environments of a lake in the southern alps. Diss. Bot. 87, 229-271 (1985).

Stuiver, M., T. F. Braziunas, B. Becker and B. Kromer: Climatic, Solar, Oceanic, and Geomagnetic Influences on Late-Glacial and Holocene Atmospheric ${ }^{14} \mathrm{C} /{ }^{12} \mathrm{C}$ Change. Quaternary Research 35, 1-24 (1991).

Wick, L.: Pollenanalytische Untersuchungen zur spät- und postglazialen Vegetationsgeschichte am Luganersee (Südtessin, Schweiz). Eclogae Geol. Helv. 82/1, 265-276 (1989).

Wick, L.: Indagini paleoecologiche al Lago Basso, Pian dei Cavalli (area dello Spluga): primi risultati. - In: Fedele, F. et al.: Preistoria e paleoambienti della Valchiavenna: Pian dei Cavalli. Clavenna 30, 9-122 (1991).

Zoller, H.: Pollenanalytische Untersuchungen zur Vegetationsgeschichte der insubrischen Schweiz. Denkschr. Schweiz. Naturf. Ges. 83, 45-156 (1960).

Züllig, H.: Untersuchungen über die Stratigraphie von Carotinoiden im geschichteten Sediment von 10 Schweizer Seen zur Erkennung früherer Phytoplankton-Entfaltungen. Schweiz. Z. Hydrol. 44(1), 1-98 (1982).

Received 26 March 1992;

revised manuscript accepted 31 July 1992. 